\title{
Flüt Eğitiminde Blues Doğaçlama Çalma Becerisini Geliştirmeye Yönelik Hazırlanan Öğretim Tasarımının Uygulamadaki Görünümü*
}

\section{An Analysis On Teaching Design Developed for Improving Blues Improvisation Skills in Flute Playing}

\section{Ferhat Çelikoğlu}

Arş. Gör, Atatürk Üniversitesi Güzel Sanatlar Fakültesi Müzik Bilimleri Bölümü

email: ferhat.celikoglu@atauni.edu.tr DORCID ID: https://orcid.org/0000-0003-3080-1944

\section{Jale Deniz}

Doç. Dr, Marmara Üniversitesi Atatürk Eğitim Fakültesi Güzel Sanatlar Eğitimi Bölümü email: j.deniz@marmara.edu.tr (DORCID ID: https://orcid.org/0000-0003-1970-3630

* Bu çalışma, "Flüt Eğitiminde Blues Doğaçlama Çalma Becerisini Geliştirmeye Yönelik Öğretim Tasarımı" başlıklı doktora tezinden üretilmiştir.

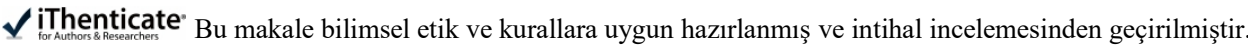

Atıf (APA 6)/To cite this article

Çelikoğlu, F., \& Deniz, J. (2020). Flüt eğitiminde blues doğaçlama çalma becerisini geliştirmeye yönelik hazırlanan öğretim tasarımının uygulamadaki görünümü. Atatürk Üniversitesi Güzel Sanatlar Enstitüsü Dergisi, 26(Müzik Özel Sayıs1), 306-313. doi: https://doi.org/10.35247/ataunigsed.640692

Makale Gönderim Tarihi/Received: 31/10/2019

Makale Kabul Tarihi/Accepted: 11/03/2020

Makale Yayın Tarihi/Published: 25/03/2020

Research Article / Araștırma Makalesi

$\ddot{O} z$

$\mathrm{Bu}$ çalıșmanın amacı, geliștirilmiş doğaçlama öğretim tasarımı ile, bireysel çalgı öğrencilerinin müzikal yaratıcılıklarının ve teme doğaçlama becerilerinin gelișip gelișmediğini ortaya koymaktır. Öğretim öncesi ve sonrasındaki doğaçlama performans ölçeği puan farklılıkları incelendiğinde, çalıșma grubunun ön test son test ortalama puanları arasında istatistiksel açıdan anlamlı bir farklılığın oluștuğu görülmüştür $(\mathrm{t}=-30,472, \mathrm{p}<.05)$. Farklılığın hangi durumdan kaynaklandığını belirlemeye yönelik olarak yapılan Bağımlı grup t test sonuçlarına göre doğaçlama öğretimi öncesi ve sonrası puan ortalamalarına bakıldığında, öğrencilerin son test puanları lehine anlamlı bir fark olduğu görülmüștür (Xöntest $=34,1429$, Xsontest $=$ 81,2500). Analiz sonuçlarına göre, doğaçlama öğretimi yapan flü öğrencilerinin doğaçlama performans beceri seviyelerinin arttığı ortaya çıkmıştır. Öz Yeterlik Algısı Ölçeği puan farklılıkları incelendiğinde, öğrencilerin öğretim öncesi ve sonrası ortalama puanları arasında istatistiksel açıdan anlamlı bir farklılığın oluștuğu görülmüştür $(\mathrm{t}=$ 9.602, $\mathrm{p}<.05)$. Farklılığın hangi durumdan kaynaklandığını belirlemeye yönelik olarak yapılan Bağımlı grup t testi sonuçlarına göre öz yeterlik ön test ve son test ortalamalarına bakıldığında, öğrencilerin son test puanları lehine anlamlı bir fark olduğu görülmüștür (Xöntest = $2, .9728$, Xsontest $=4,7755$ ). Analiz sonuçlarına göre, Blues doğaçlama öğretimi yapan flüt öğrencilerinin doğaçlama becerilerine yönelik öz yeterlik algılarının arttığı ortaya çkmıștır. Ünite kazanımlarının gerçekleşme durumlarına genel olarak bakıldığında, öğrencileri hedeflenen kazanımların büyük bir bölümünü edindiği görülmektedir. Uygun ortamda ve doğru öğretim yöntemi ile sunulan bir eğitimin, öğrenci düzeylerine göre seçilmiş içerik ve bu içeriğe yönelik hazırlanan sınavların, öğrencilerin basarılarını artırılabileceği ve öğrencileri Bilişsel- Duyuşsal ve Devinişsel alanlarda yazılan kazanımlara ulaşmalarında doğru bir araç olabileceği sonucuna ulaşılmıștır. Hazırlanan öğretim tasarımının amaçlarına uygun sonuçların ortaya çıktığı ve her öğrencinin bu program sonrasında Blues doğaçlama yapabildiği söylenebilir.

Anahtar kelimeler: Flüt, Yaratıcılık, Doğaçlama, Blues, Öğretim Tasarımı.

\begin{abstract}
The aim of this study is to determine whether individual instrument students' musical creativity and basic improvisation skills can be improved through the improved improvisation teaching design. When the improvised performance scale score differences were examined before and after teaching, it was seen that there was a statistically significant difference between the pretest posttest mean scores of the study group $(\mathrm{t}=-30,472, \mathrm{p}<.05)$. According to the results of the dependent group $t$ test, which was conducted in order to determine the situation where the difference arises, it was seen that there was a significant difference in favor of the post-test scores of the students before and after the improvisation teaching (Xpre-test $=$ $34,1429$, Xpost-test $=81,2500)$. According to the results of the analysis, it was found that the improvisation performance skill levels of the flute students increased. When the Self-Efficacy Perception Scale score differences were examined, it was seen that there was a statistically significant difference between the mean scores of students before and after teaching $(\mathrm{t}=-9.602, \mathrm{p}<.05)$. According to the results of the dependent group $t$ test, which was conducted to determine the situation where the difference arises, a significant difference was found in favor of the post-test scores of the students' self-efficacy pre-test and post-test (Xpre-test $=2, .9728$, Xpost-test $=$ $4,7755)$. According to the results of the analysis, it has been found out that the self-efficacy perceptions of the flute students who were teaching the blues improvisation skills increased. When the realizations of the unit outcomes are considered in general, it is seen that the students acquire a large part of the targeted outcomes. It has been concluded that an education provided in an appropriate environment and with the right teaching method, selected content according to student levels and the exams prepared for this content can be increased the students' success and can be the right tool for the students to achieve the achievements written in CognitiveAffective and Motivational fields.. It can be said that the results appropriate to the aims of the teaching design have emerged and that each student can perform blues improvisation after this program.
\end{abstract}

Key Words: Flute, Creativity, Improvisation, Blues, Instructional Design 


\section{Giriș}

Eğitim, bireyin davranışlarında kendi yaşantısı yoluyla ve kasıtlı olarak istendik değişme meydana getirme sürecidir. (Ertürk, 1997, s. 12). Öğretim ise, belirli bir öğrenci grubu ve belirli bir içerik için belirli bir ortamda öğrenmenin gerçekleşmesine rehberlik eden ve planlı olarak gerçekleştirilen etkinliklerden oluşan bir süreçtir. (Fer, 2015, s. 11).

Eğitim programı, "öğrenene, okulda ve okul dışında planlanmış etkinlikler yoluyla sağlanan öğrenme yaşantıları düzeneği” olarak tanımlanabilir. Bu tanımda yer alan öğrenen, yaşam boyu devam eden süreçte sürekli öğrenme arzusunda olan bireydir. Okulda ifadesi ile okul içinde yapılan tüm etkinlikler ile sınıfta öğretilen tüm dersleri içine alan öğretimi, okul dişında derken de okul çevresinde ve program dışı etkinlikler olarak dile getirilen örtük program etkinliklerini kapsadığı söylenebilir. Eğitim programı kavramının yanı sıra çok sık kullanılan diğer bir kavram da "program geliştirme" dir. Program geliştirme "eğitim programının hedef, içerik, öğrenme-öğretme süreci ve değerlendirme öğeleri arasındaki dinamik ilişkiler bütünü” olarak tanımlamak uygun görülmektedir. Bu tanımda bir eğitim programının dört temel öğesi olduğu vurgulanmaktadır. Hedef kavramı içinde öğrenene kazandırılacak istendik davranışlarda yer almaktadır. İçerik öğesi ile hedeflere uygun düşecek konular bütünü düşünülmektedir. Öğrenme- öğretme sürecinde ise hangi modellerin, stratejilerin, yöntem ve tekniklerin seçileceği belirtilmektedir (Demirel, 2015).

Seçilen bu yöntem ve teknikler 1şığına hazırlanmış eğitim programları bireylere eğitim ve öğrenme süreleri boyunca gelişim-değişim firsat sağlamaktadır. Eğitimin her alanında olduğu gibi sanat eğitimi ve alt boyutlarından bir olan müzik eğitimi üzerine geliştirilen eğitim programları da bireyin müzikal gelişiminde önemli bir yapıtaşı görevindedir.

Toplumun müzik yaşantıları dikkate alınarak hazırlanmış bir çalgı eğitim programı ve bunun yanında öğrencinin aktif olduğu, yaparak / yaşayarak öğrendiği, var olan potansiyelini ortaya çıkarabilecek bir çalg1 eğitimi süreci, kemikleşmiş bazı kalıpları kırarak, bireyin kimi nedenlerden dolayı içinde sakladığı yaratıcı yetenekleri keşfetmesini sağlayacaktır.

Belirli, çalma seviyesine gelmiş olan bir öğretmenin sadece notaya bağlı kalarak enstrümanını icra etmesi, ağırlıklı olarak tek bir türe yönelik icra yapması, içindeki yaratıcılık yönünü ortaya çıkarmakta yetersiz kalacaktır. İçinde bulunacağı koşul ve durumlar bazen anlık (spontane) çalma becerisi gerektirecektir. Müzikal doğaçlama becerisi tam olarak burada devreye girecektir.

Doğaçlama beden, uzam ve tüm insani kaynakları kullanarak, bir düşüncenin, durumun tutarlı ve anlaşılır fiziksel ifadesini, tüm çevresel uyaranların etkilerini de katarak spontan (şimdi ve burada) bir şekilde yaratmaktır. Doğaçlama ayrıca, hiçbir hazırlık yapmaksızın seyirci karşısında anında gerçekleşen performans olarak da tanımlanabilir (Tarhan, 2013, s. 9). Doğaçlama, önceden var olan bir tekniğin uygulanmasının ötesinde orijinal ve anlık bir çerçevede hareket etmeyi amaçlayan bir eylemdir.

Doğaçlamanın tüm müziksel etkinlikler içinde ilginç bir yeri vardır. Etkinliklerin en çok yapılanı olduğu halde, en az anlaşılmış olanıdır. Bugün müziğin neredeyse her alanında varken, hakkındaki bilgi yok denecek kadar azdır. Doğaçlama sürekli değişir ve yeniden uyarlanır, hiçbir zaman sabit olmaz, çözümlemeye ve kesin tanımlamaya gelmez, özü gereği kuramsal değildir. Doğaçlamayı tanımlamak için yapılan her türlü girişim, bir bakıma yanıltıcı olmaya mahkûmdur, çünkü doğaçlamanın ruhunda öyle bir şey vardır ki, belgeleme düşüncesiyle çelişir ve belgeleme amaçlarına ters düşer (Bailey, 2001, s. 9).

Doğaçlamalarda çalmak ve tanıdık ezgilerin ritmik süslemelerini yapmak kişisel kaygıları hafifletmeye yardımcı olur. Grup doğaçlama, performans stresinin azaltılmasında etkilidir. Müzisyenlerin güvenli bir çevrede yaratıcılık yoluyla dönüşümüne ve performans kaygısı ile ilgili konularda daha bilinçli olmasına yardımcı olur (Kenny ve Gellrich, 2002).

Doğaçlamanın en önemli özelliklerinden biri icracıyı sürekli geliştirmesidir. Bir kişinin veya bir grubun yapacağ müzik doğaçlama, yaratıcılık boyutunu üst seviyelere çıkarabilir. Özgür olsa da, her bir doğaçlamanın temelinde kurallar ve yönlendirici fikirler vardır (Jungmair, 2002).

Çalgı eğitiminin bir boyutu olan flüt eğitimi, flüt çalmayı öğrenebilme, flüt çalmayı geliştirebilme, çalgıyı etkin kullanabilme basamaklarını gerçekleştirecek şekilde yürütülen ve öğretim elemanı ile öğrencinin iletişimi ve etkileşimi içerisinde gerçekleştirilebilen bir eğitim sürecidir(Cüceloğlu, 2006).

Çalgı eğitiminde doğaçlama çalma becerisini geliştirecek yeni yöntem ve yaklaşımların, mevcut flüt çalma ve öğrenme geleneğinin gelişmesine olumlu yönde etki edeceği düşünülmektedir. Bir çalgı icracısının hiç bilmediği, duymadığı bir ezgiye, ritim ve armonik yürüyüşleri dikkate alarak anlık eşlik edebilmesi, şarkı sözü ve ezgi yazabilmesi çalg1 icracılığı ve öğretmenlik mesleği bakımından önem taşımaktadır. Bu doğrultuda eğitim programlarına müzik öğretmeni adaylarının müziğin yaratıcılık boyutunu ayrıntılı olarak öğrenebilecekleri ve uygulayabilecekleri içeriklerin eklenmesi önemlidir. Bir müzik öğretmeni için, müzik yaşantısı süresince 
kullanacağı en önemli aracın çalgısı olduğu düşünülürse, çalgı eğitiminde de yaratıcılık boyutuna önem verilmesi ve çalgı eğitiminin içeriğine doğaçlama öğelerinin yerleştirilmesi gerekmektedir.

Blues müziğin diğer tüm popüler türlerin oluşmasında etkisi ve doğaçlama temelli bir öğretisi olduğu dikkate alındığında, doğaçlama eğitimine Blues müzik ile başlamamım doğru bir yol olacağı düşünülmektedir. Buradan hareketle araştırmada bireysel çalgı flüt öğrencilerinin müzikal yaratıcılıklarını ve doğaçlama becerilerini geliştirmek amacıyla Blues temelli 5 ünitelik ve 7 haftalık başlangıç düzeyi doğaçlama öğretim tasarımı oluşturulmuş ve Atatürk Üniversitesi Güzel Sanatlar Fakültesi Müzik Bilimleri Bölümünde öğrenim görmekte olan, temel flüt çalma becerisini ve temel armoni bilgisini kazanmış 7 flüt öğrencisine uygulanmıştır.

Bireysel çalgı öğrencilerinin müzikal yaratıcılıklarının ve doğaçlama becerilerinin gelişip gelişmediğini ortaya koymak amacıyla yapılan bu çalışma, flüt alanında eğitim gören öğrencilerin çalgılarını mesleki yaşantılarında daha etkili ve daha verimli kullanmalarını sağlayacağından, flüt alanında öğrenim gören müzik öğretmeni adaylarının, öğretmenlikleri süresince karşılaşacakları eserlere anlık eşlik edebilmelerine katkı sağlayacağından, çalg1 eğitiminde öğrencilerin yeni bir tür ve farklı ses dizileri öğrenmelerini sağlayacağından, öğrencilerin doğaçlama, dolayısıyla müzikal yaratıcılık yönlerini geliştireceğinden önemlidir.

Nitel araştırma yöntemlerinden eylem araştırması modeli temele alınarak gerçekleştirilmiş olan ana çalışmada, veriler nitel ve nicel olmak üzere iki boyutlu olarak ele alınmıştır. Bu çalışmada ise; ön test ve son test verilerine göre, öğrencilerin doğaçlama becerileri düzeylerinde ne gibi değișiklikler olmuştur? Program öncesi ve sonrası öğrencilerin öz yeterlik düzeyleri arasında ne gibi değişiklikler olmuştur? Haftalık ölçme değerlendirme sonuçlarına göre, öğrencilerin gelişim durumları nasıl değişim göstermiştir? Sorularının cevaplandığı nicel veriler paylaşılmıştır. Doğaçlama performans verilerinin toplanması için Çelikoğlu ve Lehimler (2019) tarafindan geliştirilen "Doğaçlama Performans Değerlendirme Ölçeği”, öğrencilerin doğaçlama özyeterlik algılarının tespiti için araştırmacı tarafından geliştirilen "Doğaçlama Özyeterlik Algısı Ölçeği” ve ünite sonu sınav değerlendirmeleri için ise, ünitelere yönelik hazırlanmış ölçme testleri kullanılmıştır.

\section{Verilerin Analizi}

Araştırmada hangi testlerin kullanılacağına karar vermek amacıyla elde edilen veriler Kolmogorov- Smirnov normallik testine tabi tutulmuştur. Normallik tesit sonuçları Tablo 1'de görülmektedir.

Tablo 1

Kolmogorov-Smirnov Normallik Testi Sonuçları

\begin{tabular}{|c|c|c|c|c|}
\hline \multicolumn{5}{|c|}{ Kolmogorov-Smirnov } \\
\hline & & İstatistik & Sd & $\mathbf{p}$ \\
\hline \multirow{2}{*}{ Doğaçlama Performans Değerlendirme } & Öntest & .163 & 28 & .055 \\
\hline & Sontest & .073 & 28 & .200 \\
\hline \multirow{2}{*}{ Doğaçlama Özyeterlik } & Öntest & .216 & 7 & .200 \\
\hline & Sontest & .182 & 7 & .200 \\
\hline
\end{tabular}

Doğaçlama performans değerlendirme puanları için yapılan normallik testi sonucunda $\mathrm{p}=.05$ anlamlılık düzeyinde araştırmadan elde edilen verilerin hem ön test ( $p=.055>.05)$, hem de son testte $(p=.200>.05)$ normal dağ 1 ldığg tespit edilmiştir. Ayrıca Doğaçlama özyeterlik puanları için yapılan normallik testi sonucunda da, hem ön test $(p=.200>.05)$, hem de son testte $(p=.200>.05)$ verilerin normal dağıldığı tespit edilmiştir Bu doğrultuda, araştırmanın nicel verilerinin çözümlenmesinde Parametrik testler uygulanmıştır.

Araştırmanın ilk bölümünü olușturan performans değerlendirme ön testi için, çalıșma grubundaki 7 öğrenciye, 36 Bar F blues bir alt yapı verilmiş ve üzerine bir doğaçlama yapmaları istenmiştir. Doğaçlama sololar kamera karşısında çaldırılarak kayıtları alınmıştır. Kayıt altına alınan ön test verileri 4 uzman tarafından doğaçlama performans ölçeği kullanılarak değerlendirilmiş, elde edilen verileri analiz edebilmek için istatistik programına aktarılmıștır.

Performans değerlendirme ön testi uygulamasının ardından, Doğaçlama Öz yeterlik algısı Ölçeği kullanarak, program öncesi öğrencilerin doğaçlama ile ilgili boyutlarda kendilerini ne derecede yeterli gördükleri istatistik açıdan ortaya konulmuştur.

Yedi haftalık uygulama aşamasında, her ünite için ölçme değerlendirme sınavları yapılmış ve sonuçlar; Atatürk Üniversitesi sınav değerlendirme yönetmeliğinde yer alan "Değerlendirmeye alınan öğrenci sayısı onun altında ise, yarıyıl sonu değerlendirmesinde, öğretim elemanı bağıl notları kendi inisiyatifine göre verir" ifadesi dikkate alınarak değerlendirilmiştir. Buradan hareketle sonuçlar "0-49.99 Düşük" "50.00-69.99 Orta", "70.00-84.99 İyi”" ve "85.00-100 Çok İyi" şeklinde puanlanmıştır.

Araştırmanın son bölümünde, 7 haftalık eğitimin ardından çalışma grubundaki öğrencilere performans değerlendirme son testi uygulaması yapılmıştır. Aynı altyapı üzerine doğaçlama yapmaları istenmiş ve 
performansları tekrar kamera ile kayıt altına alınmıştır. Son testin ardından aynı 4 uzman doğaçlama performans ölçeği kullanılarak performansları değerlendirmiş ve veriler istatistik programına aktarılmıştır.

\section{Bulgular}

$\mathrm{Bu}$ bölümde, toplanan verilerin analizi neticesinde ulaşılan bulgular, bu bulguların sonuçlarına göre tablolar ve açıklamalar yapılmıştır.

\subsection{Birinci Alt Probleme Yönelik Bulgular}

Öğrencilerin doğaçlama düzeylerini ölçmek amacıyla uygulama öncesi ön test, uygulama sonrası son test uygulanmıştır. Ön test ve son test kapsamında öğrencilere F Blues altyapı dinletilmiş ardından altyapı üzerine bir doğaçlama yapmaları istenmiştir. Ön test- Son test Bağımlı Örneklem t Testi verileri Tablo 2'de verilmiştir.

Tablo 2

Çalışma Grubu Performans Ön Test- Son Test

\begin{tabular}{|c|c|c|c|c|c|c|c|}
\hline Öğrenci & Ön test-Son Test & $\mathbf{N}$ & X & SS & Sd & $\mathbf{t}$ & $\mathbf{p}$ \\
\hline \multirow{2}{*}{$\begin{array}{c}\text { Genel } \\
\text { Ortalama }\end{array}$} & Ön Test & \multirow{2}{*}{7} & 34.1429 & 6.09015 & \multirow{2}{*}{6} & \multirow{2}{*}{-30.472} & \multirow{2}{*}{$.000^{*}$} \\
\hline & Son test & & 81.2500 & 7.29091 & & & \\
\hline
\end{tabular}

Tablo 2 incelendiğinde, çalışma grubundaki öğrencilerin 4 farklı değerlendirici puanlarına göre ön test son test farklılıkları görülmektedir. Performans öntest- son test puan farklılıkları incelendiğinde, çalışma grubunun ön test son test ortalama puanları arasında istatistiksel açıdan anlamlı bir farklılığın oluştuğu görülmektedir $(\mathbf{t}=\mathbf{- 3 0 . 4 7 2}$, $\mathbf{p}<.05)$. Farklılığın hangi durumdan kaynaklandığını belirlemeye yönelik olarak yapılan Bağımlı Örneklem t Testi sonuçlarına göre ön test ve son test ortalamalarına bakıldığında, çalışma grubunun son test puanları lehine anlamlı bir fark olduğu görülmektedir (Xöntest $=\mathbf{3 4 . 1 4 2 9}$, Xsontest $=\mathbf{8 1 . 2 5 0 0}$ ). Buradan elde edilen sonuçlara bakıldığında, hazırlanmış öğretim tasarımına göre doğaçlama öğretimi yapılan flüt öğrencilerinin doğaçlama performans beceri seviyeleri artmaktadır.

\section{2. İkinci Alt Probleme Yönelik Bulgular}

Öğrencilerin özyeterlik düzeylerini ölçmek amacıyla uygulama öncesi ve uygulama sonrası doğaçlama özyeterlik algısı ölçeği uygulanmıştır. Ölçek kapsamında öğrencilere 21 maddelik soru sorulmuş, program öncesi ve sonrası elde ettikleri puanlar Tablo 3'de verilmiştir.

Tablo 3

Çalışma Grubu Doğaçlama Özyeterlik

\begin{tabular}{|c|c|c|c|c|c|c|c|}
\hline & & $\mathbf{N}$ & $\mathrm{X}$ & SS & Sd & $\mathbf{t}$ & $\mathbf{p}$ \\
\hline Özyeterlik & $\begin{array}{l}\text { Ön Test } \\
\text { Son test }\end{array}$ & 7 & $\begin{array}{l}2.9728 \\
4.7755\end{array}$ & $\begin{array}{l}.56935 \\
.16884\end{array}$ & 6 & -9.602 & $.000^{*}$ \\
\hline
\end{tabular}

Tablo 3'de çalışma grubundaki öğrencilerin özyeterlik ön test- son test farkl1lıkları görülmektedir. Buna göre, özyeterlik ön test- son test ortalama puanları arasında istatistiksel açıdan anlamlı bir farklılığın oluştuğu görülmektedir $(\mathbf{t}=\mathbf{- 9 . 6 0 2}, \mathbf{p}<\mathbf{. 0 5})$. Farklılığın hangi durumdan kaynaklandığını belirlemeye yönelik olarak yapılan Paired Samples t Testi sonuçlarına göre özyeterlik ön test ve son test ortalamalarına bakıldığında, öğrencilerin son test puanları lehine anlamlı bir fark olduğu görülmektedir (Xöntest $=\mathbf{2 . 9 7 2 8 , ~ X s o n t e s t ~}=4.7755$ ). Buradan elde edilen sonuçlara bakıldığında, hazırlanmış öğretim tasarımına göre doğaçlama öğretimi yapılan flüt öğrencilerinin doğaçlama becerilerine yönelik öz yeterlik algıları artmaktadır.

\section{3. Üçüncü Alt Probleme Yönelik Bulgular}

Müzikal Yaratıcılık, Doğaçlama ve Majör Pentatonik, Swing Ritim ve Melodi, Minör Pentatonik ve Blues (Blue Note), Solo Oluşturmada Akor Sesleri ve Akor Dizileri, Kromatik Kullanımı ünitelerinin teorik ve uygulama aşamaları tamamlandıktan sonra öğrencilerin konuları anlama düzeylerini ortaya koymak için her ünite sonunda bir ölçme değerlendirme sınavı yapılmıştır. Bu ölçme değerlendirmeler teorik ve uygulama olmak üzere iki yönlü hazırlanmıştır. Teorik aşamasında konuyla ilintili yazılı sorular sorulmuş, uygulama aşamasında ise performans sergilemeleri istenmiştir. Çalışma grubunun $(n=7)$, ünitelerin ölçme değerlendirmelerinden elde ettikleri puanlar tablolar şeklinde aşağıda verilmiştir.

Çalışma grubunun (n=7), birinci ünite ölçme değerlendirmelerinden elde ettikleri puanlar Tablo 4'de verilmiştir. 
Tablo 4

Birinci Ünite Ölçme-Değerlendirme Puanları

\begin{tabular}{|c|c|c|c|c|c|c|c|c|c|}
\hline \multicolumn{10}{|c|}{ Müzikal Yaratıcılık, Doğaçlama ve Majör Pentatonik } \\
\hline Öğrenciler & $\begin{array}{r}\text { 1. Soru } \\
\text { (Teorik) }\end{array}$ & $\begin{array}{l}\text { 2. Soru } \\
\text { (Teorik) }\end{array}$ & $\begin{array}{c}\text { 3. Soru } \\
\text { (Teorik) }\end{array}$ & $\begin{array}{l}\text { 4. Soru } \\
\text { (Teorik) }\end{array}$ & $\begin{array}{c}\text { 5.Soru } \\
\text { (Uygulama) }\end{array}$ & $\begin{array}{c}\text { 6. Soru } \\
\text { (Uygulama) }\end{array}$ & $\begin{array}{c}\text { 7. Soru } \\
\text { (Uygulama) }\end{array}$ & $\begin{array}{c}\text { Toplam } \\
\text { Puan }\end{array}$ & $\begin{array}{c}\text { Başarı } \\
\text { Durumu }\end{array}$ \\
\hline Ö 1 & 10 & 10 & 10 & 10 & 20 & 10 & 15 & 85 & Çok iyi \\
\hline Ö 2 & 10 & 6 & 10 & 10 & 20 & 10 & 10 & 76 & $\dot{I} y i$ \\
\hline Ö 3 & 7 & 8 & 10 & 10 & 20 & 15 & 15 & 85 & Çok iyi \\
\hline Ö 4 & 7 & 7 & 10 & 10 & 14 & 20 & 15 & 83 & $\dot{I y i}$ \\
\hline Ö 5 & 10 & 10 & 10 & 10 & 20 & 10 & 10 & 80 & $\dot{I} y i$ \\
\hline Ö 6 & 4 & 10 & 10 & 10 & 8 & 10 & 15 & 67 & Orta \\
\hline Ö 7 & 7 & 10 & 10 & 10 & 20 & 10 & 15 & 82 & $\dot{I y i}$ \\
\hline
\end{tabular}

Birinci ünitenin teorik bölümünde, konu kazanımları doğrultusunda hazırlanmış 4 adet açık uçlu soru sorulduğu ve öğrencilerin performanslarını ortaya koymak amacıyla 3 adet performans uygulaması yapıldığı görülmektedir. Açık uçlu soruların her bir 10 puan üzerinden, performans uygulamalarının her biri ise 20 puan üzerinden değerlendirilmiştir. Tablo 4' de, sınama sınavı teorik sorularının tamamına istenen cevabı veren sadece iki öğrenci olduğu, diğer öğrencilerin cevaplarının da istenen cevaplara yakın cevaplar olduğu görülmektedir. Öğrencilerin puanları 67 ile 85 arasındadır. Buna göre, "Müzikal Yaratıcılık, Doğaçlama ve Majör Pentatonik" ünitesinin kazanımlarına yönelik sınavda 2 öğrenci "çok iyi”, 4 öğrenci “iyi”, 1 öğrenci de "orta” derecede başarı göstermişlerdir. Genel olarak öğrenciler, ünite sınavında başarılı olmuşlardır.

Çalışma grubunun ( $\mathrm{n}=7)$, ikinci ünite ölçme değerlendirmelerinden elde ettikleri puanlar tablo 5'de verilmiştir.

Tablo 5

İkinci Ünite Ölçme-Değerlendirme Puanları

\begin{tabular}{|c|c|c|c|c|c|c|c|c|c|c|}
\hline \multicolumn{11}{|c|}{ Swing Ritim ve Melodi } \\
\hline Öğrenciler & $\begin{array}{c}\text { 1. Soru } \\
\text { (Teorik) }\end{array}$ & $\begin{array}{c}\text { 2. Soru } \\
\text { (Teorik) }\end{array}$ & $\begin{array}{c}\text { 3. Soru } \\
\text { (Teorik) }\end{array}$ & $\begin{array}{l}\text { 4. Soru } \\
\text { (Teorik) }\end{array}$ & $\begin{array}{c}\text { 5.Soru } \\
\text { (Teorik) }\end{array}$ & $\begin{array}{c}\text { 6. Soru } \\
\text { (Uygulama) }\end{array}$ & $\begin{array}{c}\text { 7. Soru } \\
\text { (Uygulama) }\end{array}$ & $\begin{array}{c}\text { 8. Soru } \\
\text { (Uygulama) }\end{array}$ & $\begin{array}{c}\begin{array}{c}\text { Toplam } \\
\text { Puan }\end{array} \\
\end{array}$ & $\begin{array}{c}\text { Başarı } \\
\text { Durumu }\end{array}$ \\
\hline$\ddot{0} 1$ & 10 & 10 & 10 & 8 & 10 & 20 & 15 & 10 & 93 & Çok iyi \\
\hline Ö 2 & 6 & 10 & 10 & 10 & 10 & 20 & 15 & 10 & 91 & Çok iyi \\
\hline Ö 3 & 7 & 10 & 10 & 10 & 10 & 20 & 15 & 7 & 89 & Çok iyi \\
\hline$\ddot{0} 4$ & 10 & 10 & 10 & 5 & 10 & 20 & 20 & 10 & 95 & Çok iyi \\
\hline Ö 5 & 5 & 10 & 10 & 5 & 10 & 15 & 10 & 7 & 72 & $\dot{I y i}$ \\
\hline Ö 6 & 6 & 7 & 8 & 10 & 10 & 15 & 18 & 7 & 81 & $\dot{I} y i$ \\
\hline Ö 7 & 10 & 10 & 5 & 8 & 10 & 20 & 10 & 7 & 85 & Çok iyi \\
\hline
\end{tabular}

İkinci ünitenin teorik bölümünde, konu kazanımları doğrultusunda hazırlanmış 5 adet açık uçlu soru sorulduğu ve öğrencilerin performanslarını ortaya koymak amacıyla 3 adet performans uygulaması yapıldığı görülmektedir. Açık uçlu soruların her bir 10 puan üzerinden, performans uygulamalarının ilk iki sorusu 20, son sorusu ise 10 puan üzerinden değerlendirilmiştir. Tablo 5' de, sınama sınavı teorik sorularının tamamına istenen cevabı veren öğrenci olmadığı, cevaplarının genel olarak istenen cevaplara yakın cevaplar olduğu görülmektedir. Öğrencilerin puanları 72 ile 95 arasındadır. Buna göre, "Swing Ritim ve Melodi” ünitesinin kazanımlarına yönelik sınavda 5 öğrenci “çok iyi”, 2 öğrenci “iyi” derecede başarı göstermişlerdir. Genel olarak öğrenciler, ünite sınavında başarılı olmuşlardır.

Çalışma grubunun (n=7), üçüncü ünite ölçme değerlendirmelerinden elde ettikleri puanlar tablo 6' da verilmiştir.

Tablo 6

Üçüncü Ünite Ölçme-Değerlendirme Puanları

\begin{tabular}{|c|c|c|c|c|c|c|c|c|c|}
\hline \multicolumn{10}{|c|}{ Minör Pentatonik ve Blues } \\
\hline Öğrenciler & $\begin{array}{c}\text { 1. Soru } \\
\text { (Teorik) }\end{array}$ & $\begin{array}{c}\text { 2. Soru } \\
\text { (Teorik) }\end{array}$ & $\begin{array}{c}\text { 3. Soru } \\
\text { (Teorik) }\end{array}$ & $\begin{array}{c}\text { 4. Soru } \\
\text { (Teorik) }\end{array}$ & $\begin{array}{c}\text { 5.Soru } \\
\text { (Uygulama) }\end{array}$ & $\begin{array}{c}\text { 6. Soru } \\
\text { (Uygulama) }\end{array}$ & $\begin{array}{c}\text { 7. Soru } \\
\text { (Uygulama) }\end{array}$ & $\begin{array}{c}\text { Toplam } \\
\text { Puan }\end{array}$ & $\begin{array}{c}\text { Başarı } \\
\text { Durumu }\end{array}$ \\
\hline Ö 1 & 10 & 10 & 7 & 10 & 15 & 10 & 20 & 82 & $\dot{I y i}$ \\
\hline Ö 2 & 6 & 10 & 10 & 10 & 15 & 15 & 10 & 76 & $\dot{I} y i$ \\
\hline Ö 3 & 10 & 9 & 8 & 10 & 15 & 15 & 10 & 87 & Çok iyi \\
\hline Ö 4 & 10 & 10 & 10 & 10 & 15 & 15 & 20 & 90 & Çok iyi \\
\hline Ö 5 & 10 & 10 & 10 & 10 & 10 & 10 & 15 & 75 & $\dot{I} y i$ \\
\hline Ö 6 & 10 & 10 & 10 & 10 & 15 & 15 & 17 & 87 & Çok iyi \\
\hline Ö 7 & 10 & 10 & 10 & 10 & 10 & 10 & 10 & 70 & $\dot{I y i}$ \\
\hline
\end{tabular}


Üçüncü ünitenin teorik bölümünde, konu kazanımları doğrultusunda hazırlanmış 4 adet açık uçlu soru sorulduğu ve öğrencilerin performanslarını ortaya koymak amacıyla 3 adet performans uygulaması yapıldığ 1 görülmektedir. Açık uçlu soruların her bir 10 puan üzerinden, performans uygulamalarının her biri ise 20 puan üzerinden değerlendirilmiştir. Tablo 6' da, sınama sınavı teorik sorularının tamamına istenen cevabı veren dört öğrencinin olduğu, diğer öğrencilerinde cevaplarının istenen cevaplara yakın cevaplar verdiği görülmektedir. Öğrencilerin puanları 70 ile 90 arasındadır. Buna göre, "Minör Pentatonik ve Blues" ünitesinin kazanımlarına yönelik sınavda 3 öğrenci “çok iyi”, 4 öğrenci “iyi” derecede başarı göstermişlerdir. Genel olarak öğrenciler, ünite sınavında başarılı olmuşlardır.

Çalışma grubunun ( $\mathrm{n}=7)$, dördüncü ünite ölçme değerlendirmelerinden elde ettikleri puanlar tablo 7' de verilmiştir.

Tablo 7

Dördüncü Ünite Ölçme-Değerlendirme Puanları

\begin{tabular}{|c|c|c|c|c|c|c|c|c|c|}
\hline \multicolumn{10}{|c|}{ Solo Oluşturmada Akor Sesleri ve Akor Dizileri } \\
\hline Öğrenciler & $\begin{array}{c}\text { 1. Soru } \\
\text { (Teorik) }\end{array}$ & $\begin{array}{c}\text { 2. Soru } \\
\text { (Teorik) }\end{array}$ & $\begin{array}{l}\text { 3. Soru } \\
\text { (Teorik) }\end{array}$ & $\begin{array}{c}\text { 4. Soru } \\
\text { (Teorik) }\end{array}$ & $\begin{array}{c}\text { 5.Soru } \\
\text { (Teorik) }\end{array}$ & $\begin{array}{c}\text { 6. Soru } \\
\text { (Uygulama) }\end{array}$ & $\begin{array}{c}\text { 7. Soru } \\
\text { (Uygulama) }\end{array}$ & $\begin{array}{c}\text { Toplam } \\
\text { Puan }\end{array}$ & $\begin{array}{c}\text { Başarı } \\
\text { Durumu }\end{array}$ \\
\hline Ö 1 & 10 & 10 & 10 & 10 & 10 & 20 & 25 & 95 & Çok iyi \\
\hline Ö 2 & 10 & 10 & 10 & 10 & 10 & 20 & 20 & 90 & Çok iyi \\
\hline Ö 3 & 10 & 10 & 10 & 10 & 10 & 25 & 25 & 100 & Çok iyi \\
\hline Ö 4 & 10 & 10 & 10 & 10 & 10 & 20 & 20 & 90 & Çok iyi \\
\hline Ö 5 & 10 & 10 & 10 & 10 & 10 & 25 & 25 & 100 & Çok iyi \\
\hline Ö 6 & 8 & 5 & 10 & 10 & 10 & 25 & 25 & 93 & Çok iyi \\
\hline Ö 7 & 10 & 10 & 10 & 10 & 10 & 20 & 15 & 85 & Çok iyi \\
\hline
\end{tabular}

Dördüncü ünitenin teorik bölümünde, konu kazanımları doğrultusunda hazırlanmış 5 adet açık uçlu soru sorulduğu ve öğrencilerin performanslarını ortaya koymak amacıyla 2 adet performans uygulaması yapıldığ 1 görülmektedir. Açık uçlu soruların her bir 10 puan üzerinden, performans uygulamalarının her biri ise 25 puan üzerinden değerlendirilmiştir. Tablo 7' de, sınama sınavı teorik sorularının tamamına altı öğrencinin cevap verdiği, bir ögrencinin ise 1. ve 2. sorularda istenen cevaplara yakın cevap, diğer üç soruya ise doğru cevap verdiği görülmektedir. Öğrencilerin puanları 85 ile 100 arasındadır. Buna göre, "Solo Oluşturmada Akor Sesleri ve Akor Dizileri” ünitesinin kazanımlarına yönelik sınavda tüm ö̆grenciler "çok iyi” derecede başarı göstermişlerdir.

Çalışma grubunun $(n=7)$, beşinci ünite ölçme değerlendirmelerinden elde ettikleri puanlar tablo 8'de verilmiştir.

Tablo 8

Beşinci Ünite Ölçme-Değerlendirme Puanları

\begin{tabular}{|c|c|c|c|c|c|c|c|c|}
\hline \multicolumn{9}{|c|}{ Kromatik Kullanımı } \\
\hline Öğrenciler & $\begin{array}{c}\text { 1. Soru } \\
\text { (Teorik) }\end{array}$ & $\begin{array}{l}\begin{array}{l}\text { 2. Soru } \\
\text { (Teorik) }\end{array} \\
\end{array}$ & $\begin{array}{l}\text { 3. Soru } \\
\text { (Teorik) }\end{array}$ & $\begin{array}{l}\text { 4. Soru } \\
\text { (Teorik) }\end{array}$ & $\begin{array}{c}\text { 5.Soru } \\
\text { (Teorik) }\end{array}$ & $\begin{array}{c}\text { 6. Soru } \\
\text { (Uygulama) }\end{array}$ & $\begin{array}{c}\text { Toplam } \\
\text { Puan }\end{array}$ & $\begin{array}{c}\text { Başarı } \\
\text { Durumu }\end{array}$ \\
\hline Ö 1 & 10 & 10 & 10 & 20 & 20 & 20 & 90 & Çok iyi \\
\hline Ö 2 & 10 & 10 & 10 & 20 & 20 & 30 & 100 & Çok iyi \\
\hline Ö 3 & 10 & 10 & 10 & 20 & 20 & 25 & 95 & Çok iyi \\
\hline Ö 4 & 10 & 10 & 10 & 20 & 20 & 20 & 90 & Çok iyi \\
\hline Ö 5 & 10 & 10 & 10 & 20 & 20 & 15 & 85 & Çok iyi \\
\hline Ö 6 & 10 & 10 & 10 & 20 & 20 & 20 & 90 & Çok iyi \\
\hline Ö 7 & 10 & 10 & 10 & 20 & 20 & 20 & 90 & Çok iyi \\
\hline
\end{tabular}

Beşinci ünitenin teorik bölümünde, konu kazanımları doğrultusunda hazırlanmış 5 adet açık uçlu soru sorulduğu ve öğrencilerin performanslarını ortaya koymak amacıyla, program süresince öğrenilen öğelere kromatik yaklaşım çeşitlerinin uygulanacağı 1 adet performans uygulaması yapıldı̆̆ı görülmektedir. Açık uçlu sorulandan ilk üçü 10 puan üzerinden ve son ikisi 20 puan üzerinden, performans uygulaması ise 30 puan üzerinden değerlendirilmiştir. Tablo 8' de, sınama sınavı teorik sorularına tüm öğrencilerin doğru cevap verdiği, görülmektedir. Öğrencilerin puanları 85 ile 100 arasındadır. Buna göre, "Kromatik Kullanımı" ünitesinin kazanımlarına yönelik sınavda tüm öğrenciler "çok iyi” derecede başarı göstermişlerdir.

\section{Sonuç ve Öneriler}

Araştırmacı tarafından geliştirilen doğaçlama öğretim tasarımı kullanılarak flüt eğitimi alan öğrencilerin doğaçlama becerilerinin gelişim durumunu ortaya koymak amaçlanmıştır. $\mathrm{Bu}$ amaç doğrultusunda araştırmada yapılan nicel veri analizleri sonucunda amaca yönelik bulgulara ulaşılmıştır. Elde edilen bu bulgulara göre sonuçlar, araştırmanın bu bölümünde, konu ile ilgili çalışmaların bulguları ile tartışılarak verilmişstir.

Blues doğaçlama öğretimi öncesi ve sonrası öğrencilerin doğaçlama becerileri arasındaki farka yönelik yapılan analizlerin sonucuna göre; flüt öğrencilerinin tamamladıkları Blues doğaçlama öğretimi sonrasında doğaçlama 
çalma becerilerinde gelişme olmuştu. Bu nedenle, doğaçlama öğretim tasarımının, öğrencilerin temel düzeyde doğaçlama çalma becerileri üzerinde olumlu yönde gelişim oluşturduğu söylenebilir. Elde edilen sonuçlar, Palmer (2013) tarafından yapılan çalışmanın sonuçları ile benzerlik göstermektedir. Çalışmada taklit yeteneği, caz teorisi bilgisi ve müzikal geçmişin, enstrümantal doğaçlama başarısına etkisi araştırılmış ve katılımcıların başarı puanlarının genel ortalamada yükseldiği görülmüştür. Norgaard, Stambaugh ve McCranie (2019) tarafından yapılan çalışmada, icra fonksiyonlarını geliştirebilmek için doğaçlama temelli çalgı eğitimi verilmiş ve doğaçlama eğitimi verilen öğrencilerin icra fonksiyonlarının geliştiği gözlemlenmiştir. Taklit becerisini kazan öğrencilerin, notasyon kullanarak çalmalarında değişim meydana geldiği görülmüştür. Güleç (2017) tarafından yapılan çalışmada da doğaçlama çalışmalarının öğrencilerin müzikal yaratıcılıklarını artırdığı gözlemlenmiştir. Ön test ve son test verileri öğrencilerin yaratıcılık düzeylerini artırdığı sonucuna varılmıştır.

Blues doğaçlama öğretimi öncesi ve sonrası öğrencilerin öz yeterlik algıları arasındaki farka yönelik yapılan analizlerin sonucuna göre; flüt öğrencilerinin tamamladıkları Blues doğaçlama öğretimi sonrasında doğaçlama öz yeterlik algılarında gelişme olmuştur. Bu nedenle temel doğaçlama öğretim tasarımının öğrencilerin özyeterlikleri üzerinde olumlu yönde gelişim oluşturduğu söylenebilir. Davison (2006) da benzer şekilde müzik teorisiyle ilişkili öğretilen doğaçlama öğreniminin, öğrenci öz yeterlikleri üzerindeki etkisini araştırmış, teorik bilgilerle birlikte verilen doğaçlama eğitimi sonrasında öğrencilerin öz yeterlik düzeylerinde anlamlı bir artış olduğunu gözlemiştir. Davison' un bulduğu bu sonuçlar, araştırma yöntem ve sonuçları bakımından örtüşmektedir Watson (2010) işitsel doğaçlamaya karşı, notalı doğaçlamaya yönelik oluşturduğu öğretim modelinin, caz doğaçlama ve öz yeterliklerine etkisine yönelik yaptığı çalışmasında, uygulama yapılan öğrencilerin uygulama öncesi ve sonrası doğaçlama öz yeterliklerinde olumlu yönde bir gelişim sağlamıştır.

Ünitelere genel olarak bakıldığında, öğrencilerin hedeflenen kazanımların büyük bir bölümünü edindiği ve ünitelere yönelik sınavlarda genel olarak başarılı oldukları görülmektedir. Uygun ortamda ve doğru öğretim yöntemi ile sunulan bir eğitimin, öğrenci düzeylerine göre seçilmiş içerik ve bu içeriğe yönelik hazırlanan sınavların, öğrencilerin başarılarını artırılabileceği ve öğrencileri Bilişsel- Duyuşsal ve Devinişsel alanlarda yazılan kazanımlara ulaşmalarında doğru bir araç olabileceği sonucuna ulaşılabilir. Umuzdaş (2010) tarafindan yapılan çalışmada, mikro öğretim yöntemiyle viyolonsel öğretimi tasarlanmış ve araştırmanın bir alt probleminde kazanımlara ulaşma durumları incelenmiştir. Uygulamalar sonunda mikro eğitim yöntemiyle çalgı eğitimi alan öğrencilerin, temiz nota ve doğru tartımla çalma, teknik, dinamik, cümleleme, akıcı ve bütünsel çalma, rahat çalma, eserleri gerçek hızlarına yakın çalma, eser çözümleme, müzikalite, deşifre, zamanı kullanma, disiplin, özeleştiri gibi boyutlarda yazılan tüm kazanımları edindiği görülüştür. Önlü (2014) tarafından yapılan çalışmada, öğretim programı ile ilgili olarak öğretim alanları sonunda süreç değerlendirmesine yönelik bilişsel, uygulama ve performans testleri yapılmıştır. Yapılan testlerde öğrencilerin aldığı puanlar 80-100 arasında olduğu ve bütün öğrenme alanları için daha önce belirlenmiş olan ölçüte göre 80-100 arası puanlar, "tamamen yeterli” kategorisine girdiği görülmüştür. Dolayısıyla, programın ölçme-değerlendirme boyutunun, programın başarılı olması için yeterli olduğu sonucuna varılmıştır.

Çalgı eğitiminde doğaçlama çalma becerisini geliştirecek yöntem ve yaklaşımlarla hazırlanmış, uygulaması yapılmış bu eğitim sonrasında;

1.Çalgı eğitiminde yapılacak program geliştirme çalışmalarında araştırmacıların, temel çalgı becerisine yönelik çalışmaların yanında, öğrencilerin müzik yaşantıları boyunca aktif kullanabileceği ve öğrencilerin yaratıcılıklarını ortaya çıkarabilecek nitelikte eylem ve çalışmalara da odaklanmaları önerilmektedir.

2.Mevcut flüt eğitiminde uygulanan bir eğitim programının olmayışı ve geleneksel yöntemle derslerin işlenmesi, bu bağlamada da tek bir türe yönelik eğitim verilmesi öğrencilerin yaratıcıklarını baskılamaktadır. Bu durumun aşılması için, çalgı öğretmenlerine/öğretim elemanlarına ders planlarında öğrencilerin yaratıcılık yönlerini geliştirecek uygulamalara yer vermeleri önerilmektedir.

3.Yapılan bu eğitimin, doğaçlama çalma becerilerini geliştirmedeki olumlu katkıları dikkate alındığında, araştırmacıların geleneksel yöntemin dışına çıkarak çeşitli müzik türlerini öğretmesi, öğrencilere kendi oluşturacakları melodik çalışmalar yaptırmaları, yaratıcılık düzeylerini artıracak her türlü müzikal materyale yer verileri önerilmektedir.

4.Yaratıcılığı gelişen bir öğrencinin kendine olan güveni artar ve müzikal olarak kendini daha doğru ifade eder. Öğrencilerin özgün ve yaratıcı ürünler ortaya koymalarını sağlayacak bir eğitim süreci, çalgıyla daha çok zaman geçirmelerini sağlayacaktır ve ayrıca öğrencilerin mesleki -akademik olarak kendilerine güvenlerini artıracaktır. Doğaçlama çalmanın öğrencilerin öz yeterliklerini attırdığı dikkate alındığında, üst düzey bilişsel ve devinişsel süreçleri hedefleyen, yaratıcılığı ve hayal gücünü ortaya çıkartan, öğrencilerin kendilerini daha özgür hissetmelerini sağlayan bir çalgı eğitimi süreci planlanmalıdır. Bunu sağlamak için müzik eğitimi verilen fakültelerde/kurumlarda, öğrencilerin yaratıcılık ve doğaçlama becerilerini geliştirecek dersler konulmalı ve bu dersler kuramdan çok uygulamaya yönelik uygulanmalıdır. 
5.Doğaçlama eğitim sürecin öğrencilerin doğaçlama becerilerini olumlu yönde etkilediği dikkate alındığında, araştırmacılar daha uzun süreli eğitimler ve doğaçlamanın üst seviyelerini içeren farklı üniteler kullanarak, araştırmalar yapabilirler.

6.Doğaçlama eğitimine ilgi duyan araştırmacılar bu kapsamda hazırlanmış bir öğretim tasarımını, farklı çalışma gruplarında (çalgılarda) ve doğaçlamanın farklı sevilerinde deneyerek sonuçlarını karşılaştırabilirler.

7.Çalgı eğitimlerinde öğrencileri başarıya ulaştıran en önemli araç, doğru kurgulanmış bir eğitim programıdır. Araştırma sonuçları da bu iddiayı doğrular niteliktedir. Buradan hareketle çalgı eğitimlerinde kullanılmak üzere her öğesi (kazanımlar, içerik, öğrenme-öğretme durumları, öğretme etkinlikleri ve sınama durumları) dikkatle hazırlanmış eğitim programları oluşturulmalı ve çalgı eğitimi bu doğrultuda yapılmalıdır.

\section{Kaynakça}

Atauni. (2019). Sinav yönetmeliği. Erişim adresi: https://webarsiv.atauni.edu.tr/sinavlarin-degerlendirilmesi

Bailey, D. (2001). Doğaçlama (A. Bucak, Çev.). İstanbul: Pan Yayıncılık.

Cüceloğlu, G. (2006). 2001 yılından günümüze müzik ögretmenliği anabilim dallarında uygulanan bireysel çalgı eğitimi (flüt) öğretim programlarının-değerlendirilmesi. Ulusal Müzik Eğitimi Sempozyumunda sunulan bildiri. Pamukkale Üniversitesi Eğitim Fakültesi, Denizli.

Çelikoğlu, F., \& Lehimler, E.(2019). Müzikal doğaçlama performans değerlendirme ölçeği: Geçerlik ve güvenirlik çalışması. Sanat Dergisi, 34, 117-125.

Davison, D. P. (2006). The Role Of Self-Efficacy And Modelıng In Improvisatıon: The Effects Of Aural And Aural/Notated Modeling Conditions On Intermediate Instrumental Music Students' Improvisatıon Achievement (Doctoral tehesis). North Texas Üniversitesi.

Demirel, Ö. (2015). Eğitimde program geliştirme. Ankara: Pegem Yayıncılık.

Ertürk, S. (1997). Eğitimde program geliştirme. Ankara: Meteksan.

Fer, S. (2015). Öğretim tasarımı. Ankara: Anı Yayıncılık.

Güleç, G. (2017). Keman çalmada doğaçlama çalışmalarının öğrencilerin müzikal yaratıcılık ve keman çalma performansları üzerindeki etkileri (Doktora tezi). YÖK Tez veri tabanından erişildi. (Tez No. 450188)

Jungmair, U. E. (2002). Orff schulwerk-carl orff anlayışı çerçevesinde elementer müzik ve dans pedagojisi. OrffSchulwerk info, 1, 5-6.

Kenny, B. J., \& Gellrich, M. (2002). Improvisation. Gary McPherson. R. Parncutt (Ed.), The science and psychology of music performance (s.117-134) içinde. New York: Oxford University Press.

Norgaard, M., Stambaugh, L. A., \& McCranie, H. (2019). The effect of jazz improvisation instruction on measures of executive function in middle school band student. Journal of Research in Music Education, 67(3), 339-354.

Önlü, A. (2014). Müzik ögretmenliği lisans programlarına yönelik saksafon ögretim programı tasarısı ve değerlendirilmesi (Doktora Tezi). YÖK Tez veri tabanından erişildi. (Tez No. 366363)

Palmer, C. M. (2013). An analysis of instrumental jazz improvisation development among high school and college musicians (Doctoral thesis). Michigan University. Erişim adresi: https://deepblue.lib.umich.edu/bitstream/ handle/2027.42/102395/cmpalm 1.pdf?sequence $=1$

Tarhan, K. (2013). Doğaçlama için elkitabı. İstanbul: Mitos Boyut Yayınları.

Umuzdaş, S. (2010). Mikro ögrretim yönteminin viyolonsel öğretmeni adaylarının öğretim becerilerine ve viyolonsel dersine ilişkin tutumlarına etkisi (Doktora Tezi). YÖK Tez veri tabanından erişildi. (Tez No. 279707)

Watson, K. E. (2010). The effects of aural versus notated instructional materials on achievement and self-efficacy in jazz improvisation. Journal of Research in Music Education, 58(3), 240-259. 